\title{
Canavan Disease as a Rare Cause of Leukodystrophy: MRI and MRS Findings
}

\author{
Nadir Bir Lökodistrofi Nedeni Olarak Canavan Hastalı̆̆ı: MRG ve MRS Bulguları
}

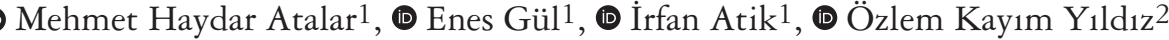 \\ ${ }^{1}$ Cumhuriyet University Faculty of Medicine, Department of Radiology, Sivas, Turkey \\ ${ }^{2}$ Cumhuriyet University Faculty of Medicine, Department of Neurology, Sivas, Turkey
}

Keywords: Brain, Canavan disease, leukodystrophy, magnetic resonance imaging

Anahtar Kelimeler: Beyin, Canavan hastalı $\breve{g}_{1}$, lökodistrofi, manyetik rezonans görüntüleme

\section{Dear Editor,}

Canavan disease (CD) is a rare autosomal recessive leukodystrophy that is characterized by spongiform degeneration of the brain white matter. In $\mathrm{CD}, \mathrm{N}$-acetyl aspartate (NAA) accumulates in the mitochondria as a result of the deficiency of aspartoacylase, an enzyme that causes the inhibition of myelin synthesis. CD is common among the Ashkenazi Jews. Its incidence ranges from $1: 200.000$ to $1: 400.000$ in non-Jewish populations. The early signs of CD are irritability and hypotonia with poor head control. The important signs of CD include macrocephaly, hypotonia, ataxia, reduced visual tracking, poor sucking ability, and intellectual disability $(1,2,3,4)$.

Our patient was a 7-year-old male who was born at term. He had signs of fixing eyes on a fixed point, loss of consciousness, and seizures in the form of arm and leg contractions every 4-6 months, which started 4 months after his birth. He had never spoken or been able to hold his head upright. He is the second among the three children of his family and has two healthy siblings. Although there was no family history of any pathological condition, the marriage of his parents was based on consanguinity. His examination was characterized by diffuse spasticity and increased deep tendon reflexes. Additionally, he was unable to make eye contact. His other systemic examinations and laboratory findings were normal. In the light of available clinical data, a cranial magnetic resonance imaging (MRI) examination was performed, which revealed symmetric hyperintensities involving bilateral white matter areas, subcortical-U fibers, globus pallidus, and brain stem white matter areas on T2-weighted images. The caudate nucleus and the putamen were spared (Figure 1A, B, C, D). The MR spectroscopy (MRS) of the left periventricular white matter showed physiological levels of choline and creatinine, but there was an increase in the level of NAA (Figure 2). He was found to have an ASPA gene mutation. The patient's consent was obtained for this study.

The radiological findings of $\mathrm{CD}$ guide its diagnosis. There were altered signal intensities (T2-weighted hyperintense, T1weighted hypointense) that were consistent with bilateral white matter degeneration on MRI. The most prominent involvement occurred in the subcortical white matter. The central white matter anatomical structures, i.e., the periventricular margin of the white matter and the internal capsule are usually preserved. While the globus pallidus and thalamus are frequently involved, the putamen and caudate nucleus are spared. These findings are characteristic signs of $\mathrm{CD}$. In MRS, there is an increase in NAA and NAA/Choline ratio in the involved regions of the brain $(1,3)$.

The differential diagnosis of CD encompasses demyelinating disorders that cause similar radiological signs. These include metachromatic leukodystrophy, adrenoleukodystrophy, PelizaeusMerzbacher disease, and Alexander disease. There is no specific therapy for $\mathrm{CD}$; however, human trials examining the role of lithium citrate, glyceryl triacetate, and topiramate have been conducted $(1,2,3,4)$.

Address for Correspondence/Yazışma Adresi: Mehmet Haydar Atalar Prof. MD, Cumhuriyet University Faculty of Medicine, Department of Radiology, Sivas, Turkey

Phone: +90 3462580289 E-mail: mhatalar@gmail.com ORCID: orcid.org/0000-0003-3076-8072

Received/Geliş Tarihi: 26.05.2020 Accepted/Kabul Tarihi: 30.09.2021 


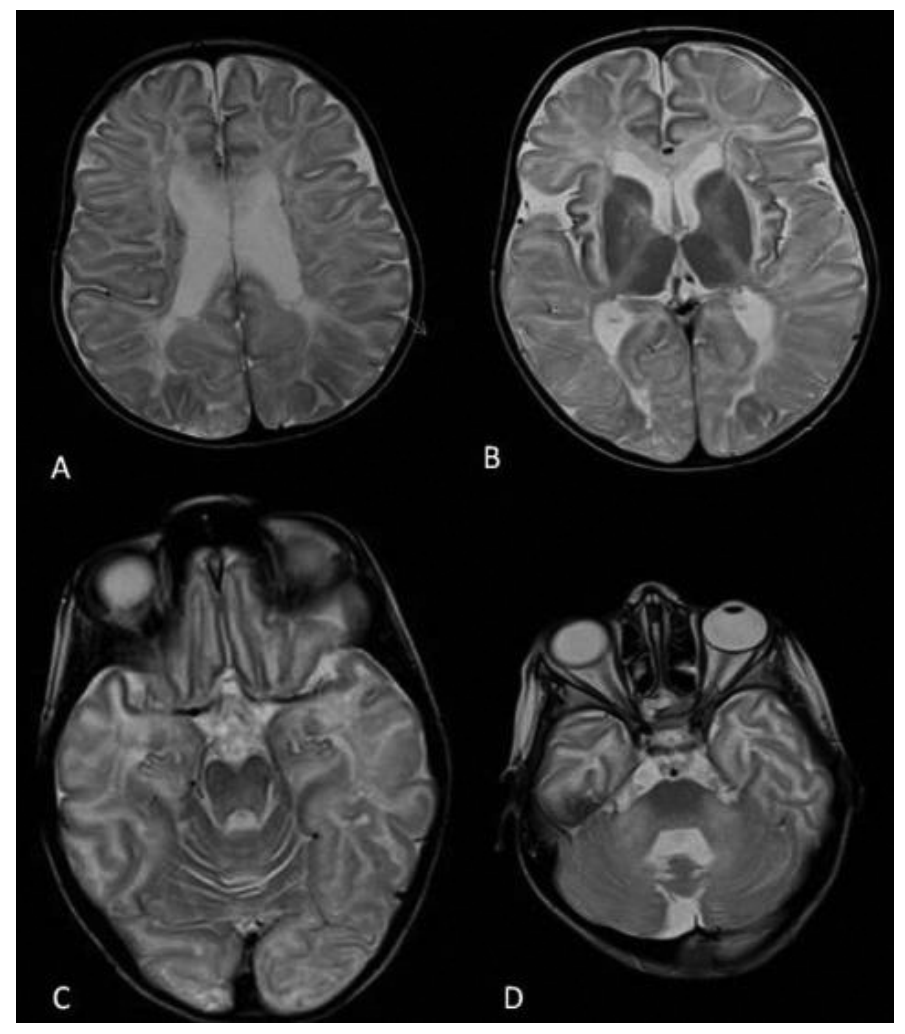

Figure 1. (A) There are hyperintense areas symmetrically involving subcortical-U fibers in the bilateral white matter on a T2-weighted image, (B) There is a hyperintense signal alteration in the bilateral cerebral white matter, globus pallidus, and thalamus on axial T2-weighted image. The caudate nucleus and putamen are spared. (C) There is an involvement of the bilateral white matter and mesencephalon's tegmentum on axial T2-weighted series. (D) The involvement is prominent in the middle cerebellar pedicle on the axial T2-weighted image

In patients with hypotonia and neuromotor developmental delay, conditions in the leukodystrophy group should be considered. In this patient group, an MRS study should be performed and a differential diagnosis for CD should also be performed. Moreover, genetic studies should be conducted for individuals diagnosed with $\mathrm{CD}$ and genetic counseling should be provided to the patient.

\section{Ethics}

Informed Consent: The patient's consent was obtained for this study.

Peer-review: Internally peer-reviewed.

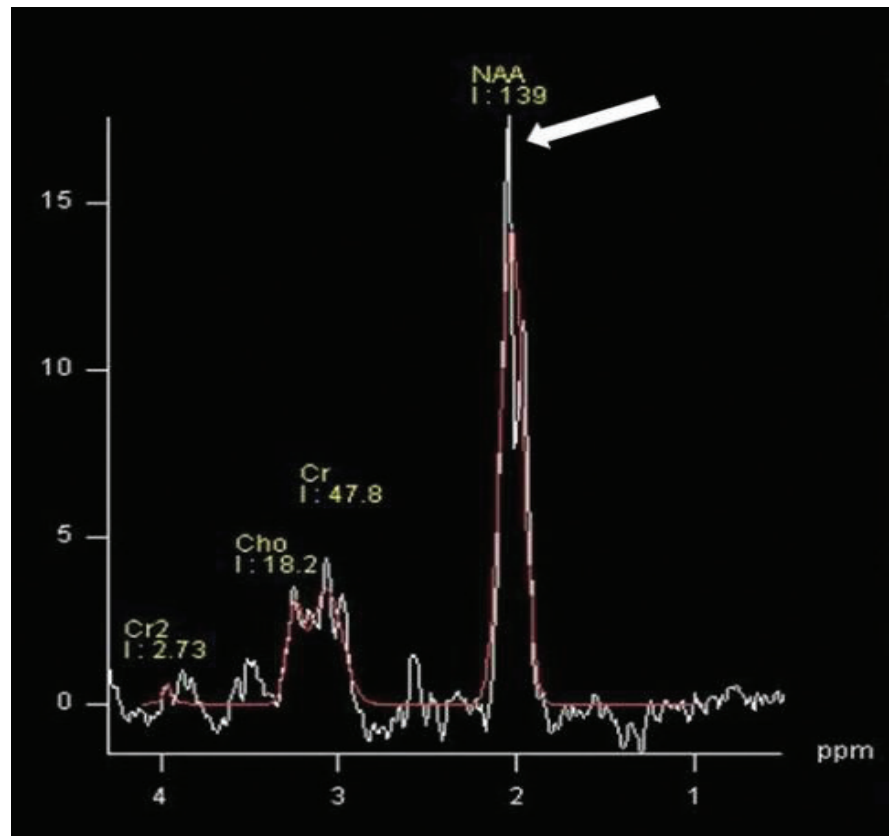

Figure 2. Magnetic resonance spectroscopy (TE: $135 \mathrm{~ms}$ ) of the affected area in the left frontal white matter shows a marked increase in the $\mathrm{N}$-acetyl aspartate peak (white arrow)

\section{Authorship Contributions}

Surgical and Medical Practices: M.H.A., E.G., Concept: M.H.A., Design: M.H.A., E.G., İ.A., Ö.K.Y., Data Collection or Processing: M.H.A., E.G., İ.A., Ö.K.Y., Analysis or Interpretation: M.H.A., E.G., Ö.K.Y., Literature Search: M.H.A., E.G., İ.A., Ö.K.Y., Writing: M.H.A., E.G., Ö.K.Y.

Conflict of Interest: No conflict of interest was declared by the authors.

Financial Disclosure: The authors declared that this study received no financial support.

\section{References}

1. Israni AV, Mandal A. Canavan disease with typical brain MRI and MRS findings. Neurol India 2017;65:1191-1192.

2. Ünlü HA, Altınbaş NK, Teber S, et al. Canavan Hastalı̆̆ı Mrg ve Mrs Bulguları: 3 Ayrı Olgu. Türkiye Çocuk Hastalıkları Dergisi 2013;7:201205 .

3. Cheon JE, Kim IO, Hwang YS, et al. Leukodystrophy in children: a pictorial review of MR imaging features. Radiographics 2002;22:461-476.

4. Hoshino H, Kubota M. Canavan disease: clinical features and recent advances in research. Pediatr Int 2014;56:477-483. 